\title{
Analysis of Value Decrease Loss Reserve Policy (Case Study in PT Bank "X”, Tbk)
}

\author{
Asyraf Firas Abdurrasyid ${ }^{1 *}$ and Evita Puspitasari ${ }^{2}$ \\ Padjadjaran University, Bandung, Indonesia
}

\begin{abstract}
This research is aimed to analyze how banks implement policies regarding impairment for allowance losses after the application of FINANCIAL ACCOUNTING STANDARD STATEMENT 50 and 55, and also to analyze how banks exercise professional judgment in their obligation to implement the impairment of the allowance losses policy.

This is a qualitative research, where the case study is used as a method of choice. The case study methods used in this research are Explanation Building and Pattern Matching. The company which is used as a subject of this research is a bank that has gone public and has implemented FINANCIAL ACCOUNTING STANDARD STATEMENT 50 and 55.

The result of the analysis using Explanation Building illustrates that the bank has fully implemented FINANCIAL ACCOUNTING STANDARD STATEMENT 55 and there are policies that are discreet to the management. The analysis which uses Pattern Matching indicates that in the process of constructing the impairment for allowance losses policy, the bank has exercised professional judgment principles based on the framework established by the Institute of Chartered Accountants Scotland.
\end{abstract}

Keywords: Accounting Policy, Case Study, Impairment for Allowance Losses, Professional Judgment

\section{INTRODUCTION}

According to the Merriam Webster Dictionary, business is an activity which covers the making, purchasing or selling goods or services which will be traded for money. The subjects of business are much varied, beginning with individual business, medium enterprises, up to international corporations. One factor which equalizes the varied businesses is the language used by the businesses, which is the business language in the form of Financial Reports which will report the history of the company in the financial structure. The aim of the financial report processing itself according to Conn Norwalk (FASB: 2008) is "to provide financial information about the reporting entity that is useful to present and potential equity investors, lenders, and other creditors in making decisions in their capacity as capital providers.”

Based on the Declaration of the Summit on Financial Markets and the World Economy, beginning in 2008 Indonesia implements the IFRS convergence up to today, where the convergence process will continuously be implemented up to when it is finished. The aim is so that the produced financial reports are easy to

* Corresponding author. Email address: fevan93@gmail.com 
understand and transparent because the applied standard is already internationally applied and increases the global investment flow. Of course this is expected to have a positive impact in the Indonesian economic growth, where all industrial sectors are expected to be able to adapt themselves with the converged standard. The industrial sector which will help support other industries is banking, where the presence of banking as fund distributors and credit providers are able to help other industries in implementing their activities.

Banking credit is a financial instrument, where the matter is a contract which is able to increase the financial assets of an entity and financial liability or equities of other entities. The presence of an accounting standard which regulates about the financial instruments are already written is FINANCIAL ACCOUNTING STANDARD STATEMENT 552011 revision about Financial Instruments: Recognition and Measurement which are consistently the same with IAS 39 which has been released by IASB. The accounting standard about banking credit itself is already written in the Indonesia Banking Accounting Guide (2008) which refers to FINANCIAL ACCOUNTING STANDARD STATEMENT 552006 revision.

In assessing their financial assets including credit, Banks correspond with FINANCIAL ACCOUNTING STANDARD STATEMENT 55 (2011 revision) and PAPI (2008), in every balance date evaluates if there is an objective proof that credit experiences value decrease. The value decrease will be admitted as a loss for the bank. Regulations about value decrease assessment for banks are explained in FINANCIAL ACCOUNTING STANDARD STATEMENT 55 (2011 revision) paragraph 65 for assessing if banks have to implement value decrease in their financial assets, based on FINANCIAL ACCOUNTING STANDARD STATEMENT 55 (2011 revision) paragraph 66, there needs to be an objective proof about the value decrease which occurs as a cause of one or more occurrences that occur after the early recognition of the asset or a disadvantageous occurrence, and the disadvantageous occurrence has an impact to the future financial asset cash flow estimation or financial asset groups which are estimated. It is also explained that objective proof which will become the financial asset indication to experience value decrease or not, covering data which are able to be observed.

If there really is an objective proof, the recorded total loss is as large as the difference between the asset recorded value with the future cash flow estimation value of now which is decreased using an effective interest rate. The asset recorded value will then be decreased by using the reserve post which is usually mentioned as Value Decrease Reserve Loss. PT Bank "X", Tbk as a part of the banking industry already implemented the FINANCIAL ACCOUNTING STANDARD STATEMENT 55 (2011 Revision) and attached the Value Decrease Reserve Loss account, this is able to be seen from its 2012 Financial Report. 


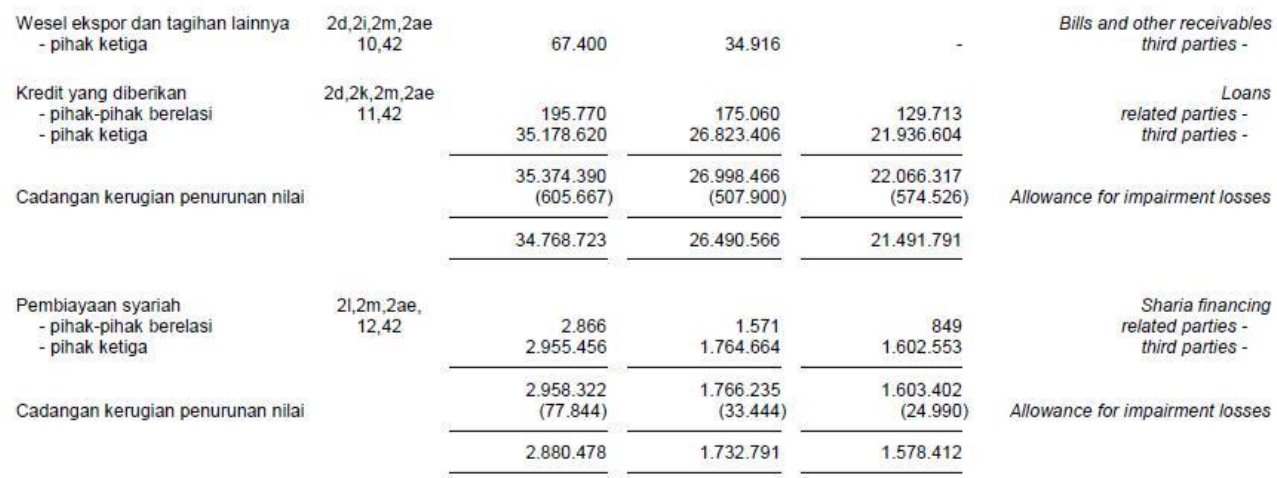

Figure 1 PT Bank "X", Tbk Financial Report

Source: PT Bank "X”, Tbk 2012 Annual Report

Which means PT Bank "X", Tbk already has a certain policy or method in determining the Value Decrease Reserve Loss post since the application of FINANCIAL ACCOUNTING STANDARD STATEMENT 55. On the basis of that the aim of this research is to learn what are the policies implemented by companies for obtaining end results for Value Decrease Reserve Loss and learn if there is a judgment process in the determination of the Value Decrease Reserve Loss after the application of FINANCIAL ACCOUNTING STANDARD STATEMENT 55. As for the research limit to be corresponding with the research aim is the Value Decrease Reserve Loss financial instrument which is researched only covers provided credit/loans.

\section{THEORETICAL FRAMEWORK}

Based on the Republic of Indonesia Act No 10 Year 1998, Credit is defined as:

"The providing of money or invoice which is able to be equalized with that, based on agreements or pacts of loaning between banks and other parties which obligates the loaning party to pay off the debt after a certain time period by giving interest"

The financial report of PT Bank "X", Tbk said that what is defined as credit are the provided credit accounts or loans. The FINANCIAL ACCOUNTING STANDARD STATEMENT 55 (2011 Revision) which is a Financial Instrument about Recognition and Measurement said that, loans which are provided and claims are non-derivative financial assets with a fixed payment or already determined and do not have quotations in the active market except: (a) The loan provided and the claim meant by the entity is for being sold in a short time, which is classed in a traded group, and the loan provided and the claim which in the early recognition by the entity is determined as a financial asset which is measured in the normal value through profit and loss; (b) the loan provided and the claim which in the early recognition is in the available group is sold; or (c) The loan provided and the claim which the owner may not obtain again the early investment substantially except 
those that are caused by the quality decrease of the provided loan and claim, and classed in the group which is available to be sold.

FINANCIAL ACCOUNTING STANDARD STATEMENT 55 (2011 Revision) mentioned in paragraph 14 that entities recognize financial assets or financial liabilities in the financial position report, if and only if, the entity becomes one of the parties in the determination of the instrument contract. It is mentioned in FINANCIAL ACCOUNTING STANDARD STATEMENT 55 paragraph 43 , that in the early recognition of financial assets or financial liabilities, entities measure in the normal value. In the matter of financial asset or liability finance is not measured in the normal value through profit and loss, the normal value is added with transaction costs which are able to be attributed directly with the acquisition or publishing of financial assets or the financial liabilities.

In paragraph 46 it is mentioned that the provided loans and claims are measured in the amortized acquisition funds by using the effective interest rate method. FINANCIAL ACCOUNTING STANDARD STATEMENT 50 (2010) about Financial Instruments: The presentation stated in paragraph 11 that, publishers of financial instruments in the early recognition categorized the instrument or the components as financial liabilities, financial assets, or equity instruments corresponding with the contractual pact substance and the definition of financial liability, financial assets, and equity instruments.

FINANCIAL ACCOUNTING STANDARD STATEMENT 60 (2010) about Financial Instruments:

The disclosure requires a disclosure based on the financial instrument group, hence the entity divides the financial instruments into groups corresponding with the said information character and considers the characteristic from the financial instrument. The entity provides enough information for making possible the reconciliation to every post row which is presented in the financial position report. Value Decrease

In the Indonesian Banking Accounting Guide (2008) it is explained that the definition of value decrease for credit is, a condition where there is an objective proof of the occurrence of a disadvantageous occurrence as a cause of one or more occurrences which occurred after the early recognition of the credit, and the disadvantageous condition has an impact to the cash flow estimation of the future to financial assets or a group of financial assets which are able to be estimated reliably.

\section{Value Decrease Loss Reserve}

The Bank Indonesia Regulation Number 14/15/PBI/2012 About Asset Quality Assessment of Public Banks defines Value Decrease Loss Reserve as an allowance which is formed if the recorded credit value after the value decrease is less than the early recorded value. The Indonesia Banking Accounting Guide (2008) said that Value Decrease Loss Reserve credit is presented as a subtracting post from "Credit" as large as the difference between the credit recorded values with the today's value estimation of cash flow of the future which is decreased using the early effective interest rate from the credit. This is later able to be seen in the financial position report. Then, the credit value decrease loss is presented as operational load in the "credit value decrease loss" post.

\section{Productive Asset Allowance Deletion}

Productive Asset Allowance Deletion is the reserve which has to be formed as large as a certain percentage from the nominal based on the division of productive 
asset quality such as determined in the Bank Indonesia Board Decree No 31/147/KEP/DIR dated November 121998 about Productive Asset Quality. The Productive Asset Allowance Deletion which has been formed by the bank is a reserve which has been formed by the bank for closing the chance of loss that arises as a cause of planting funds in troubled productive assets. Productive Asset Allowance Deletion is allowance deletion which is implemented by the manner of burdening profit and loss of the current year with the purpose for containing loss which arise as a cause of not receiving back some or all the productive assets.

With the implementation of FINANCIAL ACCOUNTING STANDARD STATEMENT 55 (2006 Revision), the Productive Asset Allowance Deletion method automatically does not apply anymore. The means of counting Productive Asset Allowance Deletion is able to be seen from the Bank Indonesia Board Decree No 31/148/KEP/DIR about the Forming of Productive Asset Allowance Deletion. This method is changed with the post of Value Decrease Loss Reserve, which the means of measuring is able to be seen in the Indonesia Banking Accounting Guide (2008 Revision). This of course will change the policy of banking industry subjects in how they apply the standard to be corresponding with the condition faced by their companies. The hypothesis in this research is that there is a policy of Value Decrease Loss Reserve in PT Bank "X", Tbk after the application of FINANCIAL ACCOUNTING STANDARD STATEMENT 55.

\section{RESEARCH METHODOLOGY}

The type of research implemented is descriptive, which the gathered data will be in the form of words or pictures, so it does not emphasize on numbers. (Sugiyono, 2013). Based on the research type which is implemented in this research, this research covers analysis and interpretation of the policy in managing Value Decrease Loss Reserve which is already determined by the company. Based on research results this will become a discourse of discussion and conclusion.

The research approach which is used is the qualitative approach. The qualitative approach is used because the problem is not yet clear and the studied object will be holistic in nature, complex, and dynamic, relations of any symptoms will be interactive (reciprocal). The application of the qualitative approach or method is used and implemented for obtaining an in depth illustration about the research object, the researcher will outline about the company policy in managing Value Decrease Loss Reserve for credit accounts which are provided which is based by applied financial accounting standards which are FINANCIAL ACCOUNTING STANDARD STATEMENT 55, FINANCIAL ACCOUNTING STANDARD STATEMENT 50 and FINANCIAL ACCOUNTING STANDARD STATEMENT 60.

Data which are used among others are the VALUE DECREASE LOSS RESERVE policy which the bank has before and after the FINANCIAL ACCOUNTING STANDARD STATEMENT 55 implementation, the recognition and measurement of provided credit accounts, the value decrease method for provided credit accounts, the judgment process in determining VALUE DECREASE LOSS RESERVE before and after the implementation of FINANCIAL ACCOUNTING STANDARD STATEMENT 55, and the implementation process of FINANCIAL ACCOUNTING STANDARD 
STATEMENT 50, 55, and 60 . For testing the validity of data the validity and reliability tests are implemented.

Data gathering is implemented with: (a) Literature Study; by learning standards and policies of banking which covers the research topic which is VALUE DECREASE LOSS RESERVE; (b) Interview, implemented to some informants and not structured in nature, the interview guide which is used is only in the form of the problem outline which will be asked; (c) Document Study, gathering documents which are related with the determination of VALUE DECREASE LOSS RESERVE in banks which will be collected later in the interview and observation, documents which will be used are the VALUE DECREASE LOSS RESERVE policy of the bank and the provided credit account count; (d) Observation, implement observation to the bank, the aim is for obtaining ease for data access which is needed for this research. The researcher plans for implementing participative observation, where the researcher will be involved with the daily activities of the bank. The researcher will specifically implement observation in the accounting division, risk management division, and law and obedience division as identified in the interview process; (e) Triangulation, implemented when the data gathering is being done and after the data gathering is finished. With this triangulation, the researcher will at once study the data credibility with several data gathering techniques and several data sources.

\section{DISCUSSION}

\section{Data Quality Test}

Validity and Reliability Test of Informant Interviews and Literature Study

This interview involves several parties which are implemented one-on-one and through e-mail with the whole interview process recorded and written. As for the respondents which are interviewed in the research as of now are: (1) The Accounting and Finance Division of the PT "X", Tbk Bank; (2) The Credit Risk Manager of the PT "X", Tbk Bank; (3) The Finance Services Authority; (4) The Operational Director of the PT "X", Tbk Bank (2011-2012).

In implementing reference gathering, the writer limits the valid reference types to the following points: (a) Journals, which are sets of writings and scientific articles. The valid journals which are used as references are journals which relate with Value Decrease Loss Reserve, the application of FINANCIAL ACCOUNTING STANDARD STATEMENT 50 and 55, professional accounting judgment, and journals which are related with research categorization; (b) Articles and others in the forms of: Regulations or rules of acts which are relevant and articles and other working papers which are relevant.

\section{The Application of the Value Decrease Loss Reserve Policy}

The Declaration of the Summit on Financial Markets and the World Economy obligates all G-20 members for using a set of globally accepted accounting standards of the past made Indonesia adapt the IFRS in the accounting standard formed by the DSAK. One of the results of this IFRS adoption produces FINANCIAL ACCOUNTING STANDARD STATEMENT 50, 55, and 60 which are standards for Financial Instruments. After the application of FINANCIAL ACCOUNTING STANDARD STATEMENT 50 and FINANCIAL ACCOUNTING STANDARD STATEMENT 55 in Indonesia, companies that 
report financial instruments in their financial reports are obliged to use the FINANCIAL ACCOUNTING STANDARD STATEMENT as a reference in implementing the activity of financial instrument reporting. This application of FINANCIAL ACCOUNTING STANDARD STATEMENT influences the banking industry which in practice implements many activities which relate with financial instruments. The banking industry which used to refer to FINANCIAL ACCOUNTING STANDARD STATEMENT 31 about Banking Accounting, has to change and refer to FINANCIAL ACCOUNTING STANDARD STATEMENT 50 and FINANCIAL ACCOUNTING STANDARD STATEMENT 55, this is in line with the Revocation Statement of Finance Accounting Standard No.4 (2009), which retracts the application of FINANCIAL ACCOUNTING STANDARD STATEMENT 31.

This causes a presence of a difference in how banks recognize, measure, present, and reveal credit (loans) after the application of FINANCIAL ACCOUNTING STANDARD STATEMENT 50 and 55. One of the striking differences is how banks have to assess loans. With this, the PPAP method is not used anymore as a basic for banks to determine the counting of reserves for credit and of course other financial assets. Yet, banks use the term Value Decrease Loss Reserve in determining reserve for bank credit.

\section{Literature Study Results}

With the application of a new standard, there will be a difference that arises before and after the application of FINANCIAL ACCOUNTING STANDARD STATEMENT 50 and 55. Before the application of FINANCIAL ACCOUNTING STANDARD STATEMENT 50 and 55, the banking industry still makes a reserve account, yet refers to Bank Indonesia Regulation 7/2/PBI/2005 about Public Bank Asset Assessment Quality. The reserve which is implemented is named as Asset Allowance Deletion, where banks are obliged to form Asset Allowance Deletion to Productive Assets and Non-productive Assets (Article 44 clause 1, PBI 7/2/PBI/2005). The asset allowance deletion will then be divided as general reserve, which is specified for Productive Assets, and specific reserve for Nonproductive Assets.

Value Decrease Loss Reserve is a term which is used for reserve accounts which is formed by the bank after the application of FINANCIAL ACCOUNTING STANDARD STATEMENT 50 and 55. Credit Value Decrease Loss Reserve is the allowance which is formed if the recorded credit value after the decrease is less than the early recorded value (PAPI, 2008). Financial assets or financial asset groups are decreased in value and the loss of value decrease already occurs, if and only if, there is an objective proof about the value decrease as a cause of one or more occurrences that occur after the early recognition of the assets (a disadvantageous occurrence) and the disadvantageous occurrence has an impact to cash flow estimation in the future of financial assets or financial asset groups which are able to be estimated reliably. Value decrease is basically caused by the impact of combination from several occurrences. The loss which is estimated to arise as a cause of future occurrences is not able to be recognized, regardless if the matter is possible to happen.

Basically the Indonesia Banking Accounting Guide divides the criteria of value decrease evaluation into two, which are individually and collectively. The 
Individual VALUE DECREASE LOSS RESERVE is able to be evaluated with the method:

a. Discounted Cash flow

b. Fair Value Collateral

c. Observable Market Price

While the Collective VALUE DECREASE LOSS RESERVE is able to be evaluated with the approach:

a. Formula Based

b. Statistical Model Analysis

i. Roll Rates Analysis

ii. Migration Analysis

iii. Vintage Analysis

iv. Default Rate

Article 49 in Bank Indonesia Regulation Number 14/15/PBI/2012 said that banks are obliged to form VALUE DECREASE LOSS RESERVE corresponding with the applied accounting standards. It is also mentioned that banks still have to count Asset Allowance Deletion to Productive Assets and Non-productive Assets which is regulated as the following. The determination of Asset Allowance Deletion Counting is still the same when banks apply Asset Allowance Deletion as a base for reserve counting, but the difference now is that Asset Allowance Deletion is not anymore the base of reserve counting, yet FINANCIAL ACCOUNTING STANDARD STATEMENT 55 is used.

One of the matters which will have an impact to the Value Decrease Reserve Loss evaluation of a credit is the quality determination of a bank credit. Credit quality itself is determined based on analysis to 3 (three) assessment factors which are business prospect, debtor performance, and the ability to pay. The determination of credit quality is implemented by considering significance and materiality from the three assessment factors and each of their components, and their relevance to the relevant debtor characteristics. Credit quality is set in 5 (five) assessment categories, which are Smooth, In Specific Attention, Less Smooth, Doubted, or Jammed (SEBI No 15/28/DPNP).

\section{Observation and Interview Results}

Based on the obtained observation and interview results it is seen that the application of the Value Decrease Reserve Loss policy refers to FINANCIAL ACCOUNTING STANDARD STATEMENT 55 and the Indonesia Banking Accounting Guide and the policies which are already issued by Bank Indonesia, The VALUE DECREASE LOSS RESERVE count itself is divided into two, there are Individual and Collective VALUE DECREASE LOSS RESERVE. Credit which is assessed with the Individual VALUE DECREASE LOSS RESERVE the future cash flow estimation will be counted first, if the future cash flow estimation is less than the recorded value, a value decrease has occurred, the difference will be recognized as a loss and a VALUE DECREASE LOSS RESERVE deposit adder. Credit which is assessed with Collective VALUE DECREASE LOSS RESERVE is by multiplying the credit recorded value with Probability of Default times the Loss Given Default, then the count results will be recognized as value decrease loss and as a VALUE DECREASE LOSS RESERVE deposit adder.

The bank Individual VALUE DECREASE LOSS RESERVE evaluation method will use a cash flow estimation or discounted cash flow, then compare it 
with the recorded value of the relevant credit, if the discounted cash flow value is less than the recorded credit value, the bank will recognize the presence of an increase in the VALUE DECREASE LOSS RESERVE deposit and recognize the loss of value decrease. For Collective VALUE DECREASE LOSS RESERVE banks use the roll rates analysis method, where VALUE DECREASE LOSS RESERVE will be obtained when Carrying Amount credit is multiplied with the Probability of Default percentage and Loss Given Default. Probability of Default is explained as a measure of probability (percentage) of decreasing collectability credit. While Loss Given Default is defined as a measure (percentage) where credit which are already ledger deleted are able to be billed back. It is also mentioned that banks determine the percentage of Probability of Default and Loss Given Default using machines or software which will process the percentage of Probability of Default and Loss Given Default based on the relevant historical data.

\section{Judgment in Forming Value Decrease Loss Reserve}

\section{Principle Based Accounting}

The financial report arranged by PT Bank X, Tbk already uses regulations which covers Financial Accounting Standard Statement, where the Financial Accounting Standard Statement is already based on the IFRS convergence which is implemented by the Board of Financial Accounting Standards. The convergence to IFRS causes the finance accounting standard to be based on principle or what is usually known as principle based accounting. In the article written by Black, Hopper and Band (2007), in general terms, regulations based on principle means staying away from dependence from detailed regulations and perspectives, and begin to depend on regulations which are high level, broadly stated or principle which are able to form standards where companies are able to implement their business activities. Continued in this article, that the profit which will be obtained by using the basics of this principle is offering flexibility, and being more possible for producing a behavior that fulfills the regulator objective, and easier to obey.

In the report discussed by ICAS (The Institute of Chartered Accountants Scotland) stated that they realize that by focusing on one principle, which is supported by a reliable guide for making standards which is able to be used, it will burden the practitioners and auditors of financial reports to implement professional judgment and that needs regulators and users from financing reports for considering the benefit of fair presentation, or a view which is fair to risks. ICAS believes that the risk will decrease if there is enough disclosure based on implemented judgment and that market forces will recognize the quality of the disclosure in disclosing the meaning of the formed judgment.

\section{Professional Judgment Framework}

ICAS issued A Professional Judgment Framework for Financial Reporting which contains about framework which is able to be used by practitioners, auditors, and regulators in implementing professional judgment. This framework is already prepared for helping in determining the right accounting treatment for certain transactions or transaction groups where there is no specific standard about the transaction, there is a specific standard but there is no detailed provision about the implementation, there are accounting principles in a standard but there are no detailed provisions in the principle implementation, none more than one set from the accounting principles which are able to be applied in the transaction. 
The focus of this framework is for implementing judgment in an accounting treatment for a certain transaction, yet it is easily adapted for other judgment, for example in materiality, the disclosure in the financial report or narrative report, or in a relation to accounting estimation where there is a degree of uncertainty and subjective in nature. There are four principles which cover professional judgment framework for practitioners which are, Knowledge Gathering and Analysis, Assessment of Accounting Guidance, Process for Making a Judgment, and Documentation of Judgment Standards and Regulations.

The Financial Accounting Standard Statement 25 (2009) stated that accounting policies are principles, basics, conventions, regulations and practice which are certain and applied by entities in the arrangement and presentation of financial reports. When a Financial Accounting Standard specifically applies for a transaction, occurrence, or other conditions, the applied accounting policy for the item uses the relevant Financial Accounting Standard and considers the Financial Accounting Standard application guide which is relevant. The Financial Accounting Standard will determine accounting policies for producing financial reports which contains relevant information and reliable to transactions, occurrences and other conditions.

There are several techniques of value decrease evaluation which are able to be used by banks in counting VALUE DECREASE LOSS RESERVE collectively and individually. In selecting and using value decrease evaluation techniques, banks need to consider the cost analysis and benefit and the information availability and historical data. The evaluation to value decrease is not only based on an approach or method which is standard but also based on experienced credit judgment by the party which has competence and authority remembering historical loss experience as well as data which are able to be observed are limited or maybe not fully relevant with the condition today.

\section{Observation and Interview Results}

Based on the obtained observation and interview, it is able to be said that judgment in the forming process of Value Decrease Loss Reserve is implemented partially, in the implementation the bank management already formed the Value Decrease Loss Reserve policy based on accounting standards and regulations that apply. So when forming Value Decrease Loss Reserve the bank will follow the policy which is already determined by the internals of the bank, yet there is also a regulation that suggests banks to use judgment in handling certain cases which are related with the forming of Value Decrease Loss Reserve.

\section{Case Study Analysis}

Analysis Result of the First Question and Descriptive Discussion

In the first question for answering how is the policy applied by PT Bank " $\mathrm{X}$ " Tbk for measuring the Loss Reserve post. Value Decrease for the Credit account which is Provided/Loans after the application of Financial Accounting Standard Statement 55, the analysis will be implemented using two qualitative analysis instruments which are the rationalistic qualitative and Explanation Building.

In the application of their policies, banks use credit collectability as an indication of credit value decrease, where that collectability is able to be seen from the exactness of the debtor's payment itself. When the debtor always keeps his obliged payment, it is able to be said that the debtor does not experience difficulty 
in fulfilling his obligation, so the debtor's credit is able to be categorized as Smooth. Yet if the debtor experiences tardiness in credit payment, the collectability of the debtor will decrease, causing the presence of category movement. This is based on the quality assessment of a credit which is explained in PBI No. $14 / 15 / \mathrm{PBI} / 2012$ it is explained that the quality of a credit is determined in 3 assessment factors which are Business prospect, Performance (debtor performance); and Paying ability. Yet the bank chooses paying ability as the determining factor of PT Bank " $\mathrm{X}$ " Tbk credit quality assessment.

The bank respectively explains that they have a term for the credit component quality. Collectability 1 means Smooth, Collectability 2 means In Specific Attention, Collectability 3 means Less Smooth, Collectability 4 means Doubted, and Collectability 5 means Jammed. After determining the indication when and how the reserve of a credit has to be formed, then what is next is how the process of forming the Value Decrease Loss Reserve account is. The bank mentions that they evaluate Value Decrease Loss Reserve by dividing it into Individual Value Decrease Loss Reserve and Collective Value Decrease Loss Reserve. This is also explained in the Indonesia Banking Accounting Guide that the criteria of value decrease evaluation is implemented individually or collectively.

The policy of PT Bank "X" Tbk stated that for the credit to be evaluated with collective Value Decrease Loss Reserve, the respective credit is a credit with a ceiling of above Rp 1 Billion which is in the 1 and 2 Collectability (Smooth or In Specific Attention), and credit with a ceiling of below Rp 1 Billion. While for a credit to be evaluated with individual Value Decrease Loss Reserve, the respected credit is a credit with a ceiling of above Rp 1 Billion which is in the 3,4 , and 5 Collectability (Less Smooth, Doubted, and Jammed) and reconstruction credit.

By using Explanation Building, it is able to be known what becomes the base of the bank in forming Value Decrease Loss Reserve for Credit financial assets and the implication to finance reporting. Based on comparative analysis results between Financial Accounting Standard Statement 55, Indonesia Banking Accounting Guide, Bank Indonesia Circular Letter No 15/28/DPNP to Value Decrease Loss Reserve policy of PT Bank "X", Tbk, it is able to be concluded that the bank has implemented what is recorded in the standard and related regulation with the Value Decrease Loss Reserve forming, yet it is not yet studied in depth about the occurrence process of that matter.

\section{Analysis Result of the Second Question and Descriptive Discussion}

In the second question, for answering how professional judgment is used in the counting policy of Value Decrease Loss Reserve of PT Bank "X", Tbk, the analysis will use two analysis instruments, Pattern Matching and rationalisticqualitative. By using Pattern Matching it is able to be concluded that some actions of the bank in forming Value Decrease Loss Reserve policy already follows the judgment principle which ICAS formed, although in the implementation the bank does not have a frame of professional judgment.

Deloitte (2010) in an article explained that a judgment framework will be an addition which is useful for IFRS transition by triggering more consideration to facts and information which are used in decision making, strategy for decreasing bias, and an increase in considering accountability and the continuity of judgment itself. 
The Institute of Chartered Accountants Scotland (ICAS) issued A Professional Judgment Framework for Financial Reporting which contains about framework which is able to be used by practitioners, auditors, and regulators in implementing professional judgment. This framework is already prepared for helping in determining the right accounting treatment for certain transactions or transaction groups where one of them is, there are more than one set of accounting principles which are able to be applied to the transaction. It is explained in the interview that the bank in forming Value Decrease Loss Reserve refers to the related Financial Accounting Standard, the related Bank Indonesia Regulation, and the Indonesia Banking Accounting Guide. Where there is more than one regulation which is able to be attributed in forming Value Decrease Loss Reserve policy.

The Framework Professional Judgment for practitioners (preparers) which is suggested by ICAS contains four principles which are able to be references in how the bank forms policies about Value Decrease Loss Reserve. The first principle is Knowledge Gathering and Analysis, where it is explained that a professional accounting judgment is only able to be taken when all relevant information is already gathered and analyzed. The bank explained when beginning to form policies about Value Decrease Loss Reserve there are many points to be learned because of Financial Accounting Standard Statement 55 and the Indonesia Banking Accounting Guide at the time are new matters which will be applied. So the bank feels a need for increasing human resources about this matter, the bank then organized training for its employees to understand more about the new standard.

The second principle of this framework is the Assessment of Accounting Judgment where it is explained that an accounting judgment which is professional is able to be determined with the accounting framework context which are able to apply accounting standards and other relevant literature. It is already explained that the bank when forming Value Decrease Loss Reserve policy refers to the related Financial Accounting Standard Statement, Bank Indonesia Regulations, and the Indonesia Banking Accounting Guide. The matter explains some points which are present in the second principle, which are, referring to conceptual framework for observing the principle of expansive to the definition, recognition and measurement of assets, liabilities, income, and expense. Then, also refer to accounting documents which are authoritative for additional guide, and also consider accounting standards in one's own Country or other countries.

The third principle outlines about the Process for Making a Judgment, where a professional accounting judgment is able to be determined after implementing the rightly done process. After obtaining information and producing analysis in the first and second principles, the entity will consider and assess alternatives from an accounting treatment. The matter is able to be seen from the bank when determining the Value Decrease Loss Reserve evaluation method which the bank implements for Collective Value Decrease Loss Reserve and Individual Value Decrease Loss Reserve. When determining the evaluation method for Individual Value Decrease Loss Reserve, the bank wants to use a method which is relevant and logical, so it uses discounted cash flow when compared to the two other methods. Where discounted cash flow is corresponding with data the bank obtains from a debtor. While for Collective Value Decrease Loss Reserve, the bank uses roll rate analysis because the method reflects the risk profile of each credit which is already calculated by the bank compared with other methods, with the reason the 
Value Decrease Loss Reserve is present in case there is a loss of credit from the debtor.

The fourth principle is Documentation of Judgment which is where a professional accounting judgment has to be documented in corresponding. It is explained by the bank that each division will form their own Standard Operating Procedures about the forming of Value Decrease Loss Reserve, which influences related divisions. The example is, the accounting division forming a policy about the Value Decrease Loss Reserve evaluation, then the Risk Management division forms a Value Decrease Loss Reserve counting method for retesting with what is already formed. Then the credit division will form provisions about credit classification for credit products. This is suitable with a few points which are present in the fourth principle, which has to take note of some matters in paperwork documentation which are, the last judgment achieved; relevant accounting literature which are considered; and making disclosure from important judgment, materials, or significance in the financial report.

Yet, because of limited data, and because the policy is unable to be obtained in the form of documents and documentation, the grouping of the fourth principle to the bank policy is only able to be explained in scratch. By using Pattern Matching, it is able to be concluded that some actions of the bank in forming the Value Decrease Loss Reserve policy already follows the judgment principle formed by ICAS, although in the implementation the bank does not have a frame of professional judgment.

\section{CONCLUSION AND SUGGESTIONS Conclusion}

Based on the qualitative test accompanied with discussion using an explorative and explanatory case study, the following conclusion is drawn:

a. The bank has arranged a policy in forming Value Decrease Loss Reserve after the application of Financial Accounting Standard Statement 55. The process of how the bank forms Value Decrease Loss Reserve for provided credit accounts is already explained in the outline in chapter IV. So the bank already implements Financial Accounting Standard Statement and regulations related with Value Decrease Loss Reserve, though still in the credit financial assets. This matter is able to be seen from the comparison of Financial Accounting Standard Statement, Indonesia Banking Accounting Guide, SEBI and the steps implemented by the bank in the implementation.

b. The policy formed about Value Decrease Loss Reserve after matched with Professional Judgment Framework which is arranged by ICAS, turned out to have some conformity after comparing the applied principles from the framework with actions which are already implemented by the bank in the process of Value Decrease Loss Reserve policy. So it explains how the bank implements professional judgment in forming Value Decrease Loss Reserve.

\section{Suggestions}

In corresponding with the conclusion written above, it is able to be provided suggestions to PT Bank "X", Tbk as the research object and also to researchers 
which will be interested in continuing this research. Suggestions which the writer will provide is as the following:

a. For PT Bank "X", Tbk

i. The result of this research states that the bank already succeeds in forming a policy for Value Decrease Loss Reserve, yet now it is just only in the financial credit assets. So the bank has the ability for applying a similar matter for other financial assets, it is expected for the matter to be implemented.

ii. The bank is expected to be able to continuously update in the development of accounting standards and regulations which will influence the banking industry, so the accounting policy which the bank implements is able to be developed to be able to produce quality financial information.

b. For future researchers

This research has not yet studied in depth about the process of forming Value Decrease Loss Reserve Policy, as a cause of the limited time and minimal funds from the researcher, and the respondents which have to be increased. The next researcher is able to widen the interview respondents, not fixated on one research subject, yet add it and implement it in depth, so the pattern in the banking industry is able to be seen in the matter of the passed process by the bank in forming policy and judgment which it contains inside.

\section{References}

Bank Indonesia. (2008). Pedoman Akuntansi Perbankan Indonesia (Revisi 2008). Tim Penyusun Pedoman Akuntansi Perbankan Indonesia - Ikatan Akuntan Indonesia. Jakarta

Bank Indonesia. (2012). Peraturan Bank Indonesia Nomor 14/15/PBI/2012 Penilaian Kualitas Aset Bank Umum. Tambahan Lembaran Negara Republik Indonesia Nomor 5354.

Bank Indonesia. Peraturan Bank Indonesia Nomor 7/2/PBI/2005. Pembentukan Penyisihan Penghapusan Aktiva Produktif. 2005.

Bank Indonesia. Surat Edaran Bank Indonesia Nomor 27/5/UPPB. 25 Januari 1995

Bank Indonesia. Surat Edaran Bank Indonesia Nomor 15/28/DPNP. Juli 2013.

Bank Indonesia. Surat Keputusan Direksi Bank Indonesia Nomor 31/147/KEP/DIR. Kualitas Aktiva Produktif. 12 November 1998.

Barrows, S., \& Mahidar, V. (2010). Judgment Sustained. Delloite Review

Baxter, P., \& Jack, S. (2008). Qualitative Case Study Methodology: Study Design and Implementation for Novice Researchers. The Qualitative Report, 13(4).

Black, J., Hopper, M., \& Band, C. (2007). Making a success of Principles-based regulation. Law and Financial Markets Review 
Analysis of Value Decrease Loss Reserve Policy

(Case Study in PT Bank "X", Tbk)

Bungin, B. (2007). Penelitian Kualitatif: Komunikasi, Kebijakan Publik, dan Ilmu Sosial Lainnya. Jakarta: Kencana

Caratri, E. Implikasi Penerapan PSAK 50 dan 55Revisi 2006 pada Dunia Perbankan.

http://vibizmanagement.com/column/index/category/financial/2366.

Desember 2013

Febriani, E. C. Analisis Penerapan PSAK 55 atas CKPN. 2013. Jurnal EMBA, 1(3), Juni 2013

G-20 Summit. Declaration of the Summit on Financial Markets and the World Economy. 15 November 2008. Washington DC

G20 Summit. Action Plan for Recovery and Reform . 2 April 2009. London

Kieso, W., \& Warfield. (2011). Intermediate Accounting (Volume 1 IFRS Edition). John Wiley and Sons, Inc.

Hronsky, J. (2010). IFRS 9, Impairment And Procyclicality: Is The Cure Worse Than The Disease. Journal of Applied Finance, 4.

Ikatan Akuntan Indonesia. Pernyataan Standar Akuntansi Keuangan No. 30 (Revisi 2000) Perbankan. Dewan Standar Akuntansi Keuangan-Ikatan Akuntan Indonesia. Jakarta.

Ikatan Akuntan Indonesia. Pernyataan Standar Akuntansi Keuangan No. 55 (Revisi 2011) Instrumen Keuangan: Pengakuan dan Pengukuran. Dewan Standar Akuntansi Keuangan-Ikatan Akuntan Indonesia. Jakarta.

Ikatan Akuntan Indonesia. Pernyataan Standar Akuntansi Keuangan No. 50 (Revisi 2010) Instrumen Keuangan: Penyajian. Dewan Standar Akuntansi KeuanganIkatan Akuntan Indonesia. Jakarta.

Ikatan Akuntan Indonesia. Pernyataan Standar Akuntansi Keuangan No. 60 (Revisi 2010) Instrumen Keuangan: Pengungkapan. Dewan Standar Akuntansi Keuangan-Ikatan Akuntan Indonesia. Jakarta.

Ikatan Akuntan Indonesia. Pernyataan Standar Akuntansi Keuangan No. 1 (Revisi 2009) Penyajian Laporan Keuangan. Dewan Standar Akuntansi KeuanganIkatan Akuntan Indonesia. Jakarta.

Ikatan Akuntan Indonesia. Pernyataan Standar Akuntansi Keuangan No. 25 (Revisi 2009) Kebijakan Akuntansi, Perubahan Estimasi, dan Kesalahan. Dewan Standar Akuntansi Keuangan-Ikatan Akuntan Indonesia. Jakarta.

Ikatan Akuntan Indonesia. Pernyataan Pencabutan Standar Akuntansi Keuangan No. 4. 2009. PSAK 31 Akuntansi Perbankan, PSAK 42 Akuntansi Perusahaan Efek, dan PSAK 49 Akuntansi Reksa Dana. Dewan Standar Akuntansi Keuangan-Ikatan Akuntan Indonesia. Jakarta.

Institute of Chartered Accountants Scotland. (2012). A Profesional Judgment Framework for Financial Reporting. Edinburgh. ICAS 
Institute of Chartered Accountants Scotland. (2006). Principles-Based or RuleBased Accounting Standards? A Question of Judgment. Edinburgh. ICAS

International Accounting Standard Board (IASB). (2010). Conceptual Framework for Financial Reporting 2010. UK-IASB. London

Irawan, P. (2004). Logika dan Prosedur Penelitian. Pengantar Teori dan Paanduan Praktis Penelitian Sosial Bagi Mahasiswa dan Peneliti Pemula. Jakarta: STIA LAN Press.

Wibawa, J. A. (2008). Pengaruh Risiko Kredit, Penyisihan Penghapusan Aktiva Produktif dan Tingkat Kecukupan Modal (CAR) Terhadap Likuiditas Bank. [Skripsi]. Universitas Padjadjaran Bandung

Kamus Besar Bahasa Indonesia. Kebijakan. http://kbbi.web.id/bijak. 4 Maret 2014

McConnell, P. The Objective of Financial Reporting and the Qualitative Characteristics of Useful Information - What Investors Should Know. http://www.ifrs.org/Investor-resources/2011-perspectives/January-2011perspectives/Pages/objective-of-financial-reporting.aspx. 18 Desember 2013

Merriam Webster Dictionary. 2 Desember 2013. Business. http://www.merriamwebster.com/dictionary/business

Moleong, J. L. (2013). Metodologi Penelitian Kualitatif. Bandung: PT Remaja Rosdakarya.

Neuman, W. L. (2000). Social Research Methods: Qualitative and Quantitative Approaches (4th Edition). Boston: Allyn and Bacon.

Januarika, R. (2012). Perbedaan Resiko Kredit Industri Perbankan Sebelum dan Setelah Penerapan PSAK 55 (Revisi 2006) Mengenai Instrumen Keuangan: Pengakuan dan Pengukuran. [Skripsi]. Universitas Padjadjaran, Bandung.

Stake, R. E. (1995). The Art of Case Study Research. California: Sage Publication.

Sugiyono. (2013). Metode Penelitian Kuantitatif, Kualitatif, dan R\&D. Bandung: Alfabeta.

Undang-Undang Republik Indonesia Nomor 10 Tahun 1998 Perbankan. 10 November 1998. Lembaran Negara Republik Indonesia Tahun 1998 Nomor 182. Jakarta.

. (2007). Penelitian Kualitatif \& Kuantitatif Untuk Ilmu-Ilmu Sosial. Jakarta. DIA FISIP UI.

Yin, R. K. (2003). Realibility And Validity Qualitative Reliability. New York: Amazon.ca

Yin, R. K. (2003). Case Study Research: Design and Methods. California: Sage Publication. 